\title{
KAJIAN ORGANISASI RUANG TERHADAP EMBARKASI DI KM. SINABUNG PT. PELNI TIPE 2000 PAX
}

\author{
Muhammad Afif Firas ${ }^{1}$, Dona Saphiranti ${ }^{2 *}$ \\ Institut Teknologi Bandung ${ }^{1}$, Institut Teknologi Bandung ${ }^{2}$ \\ *Correspondence author: Muhammad Afif Firas, afiffiras1@gmail.com, Bandung, Indonesia
}

\begin{abstract}
Abstrak. KM. Sinabung PT. PELNI merupakan fasilitas transportasi laut yang menghubungkan antara Pulau Jawa dan Wilayah Indonesia Timur. Salah satu aktivitas di dalam KM. Sinabung adalah embarkasi yakni proses masuknya penumpang ke dalam kapal. Berdasarkan hasil observasi, terjadi keramaian dan kontak fisik pada jalur sirkulasi disebabkan oleh penumpang yang kebingungan dalam menentukan jalan menuju kamar atau tempat tidur. Hal ini menimbulkan permasalahan kenyamanan bagi penumpang. Dalam menentukan arah jalur sirkulasi oleh penumpang sangat di pengaruhi oleh organisasi ruang, faktor internal manusia dan informasi yang tersedia. Metode yang dilakukan dalam penelitian ini adalah metode kualitatif. Pengumpulan data dilakukan melalui observasi penumpang dan observasi lingkungan, analisis komparatif dilakukan dengan membanding data antara teori kevin lynch dan hasil observasi jalur sirkulasi secara deskriptif. Pada penelitian ini ditemukan empat titik kendala yang menjadi area kebingungan penumpang untuk menentukan arah. Solusi mengatasi hal tersebut adalah dengan memperluas area bordes tangga sirkulasi 1 .
\end{abstract}

Kata kunci : organisasi ruang, embarkasi, kapal penumpang.

\begin{abstract}
KM. Sinabung PT. PELNI is a sea transportation facility that connects Java Island and Eastern Indonesia Region. One of the activities in KM. Sinabung is embarkation, which is the process of entering passengers onto the ship. Based on the results of observations, there was a crowd and physical contact on the route caused by confused passengers in determining the way to the room or bed. This raises comfort problems for passengers. In determining the direction of the passenger circulation path is very much determined by the organization of space, internal human factors, and available information. The research applied a qualitative approach. Data collection was carried out through passenger observation and environmental observation. Comparative analysis was carried out with data between Kevin Lynch's theory and observation pathway in descriptive. In this study, we found four places that became areas of confusion in determining direction. The solution to overcome this problem is to expand the border of stairs area 1.
\end{abstract}

Keywords : space organization, embarkation, passenger ship.

\section{Pendahuluan}

KM. Sinabung merupakan salah satu kapal milik PT. PELNI (Persero) yang termasuk tipe 2000 pax yakni dapat mengangkut barang dan penumpang dengan kapasitas 2000 orang(PELNI, 2020). Rute perjalanan KM. Sinabung mulai dari Jawa menuju Indonesia Bagian 
Timur yakni Pelabuhan Tanjung Perak Surabaya menuju Makassar - Baubau - Banggai - Bitung Ternate - Tidore - Baban (Bacan) - Sorong - Manokwari - Biak sampai ke Jayapura Papua dan sebaliknya. (Yahya kuncoro, 2020). KM. Sinabung merupakan kapal buatan Meyer Welf Papenburg Jerman (Werft, 2014). KM. Sinabung hanya dapat digunakan di perairan tropis Indonesia. KM. Sinabung terdiri atas 10 dek atau lantai utama dengan dek 1 hingga dek 7 merupakan dek yang dapat diakses oleh penumpang. Sedangkan dek 7 hingga 9 merupakan area kru kapal yang bertugas dan mengatur perjalanan kapal. Didalam KM. Sinabung terdapat kamar utama dan fasilitas penunjang. Kamar utama berupa kamar kelas ekonomi, kamar kelas 2C-2D, dan kamar kelas 1A-1B. Sedangkan fasilitas penunjang berupa area informasi, musholla, restoran, pantri, mini teater, café, dan balkon luar.

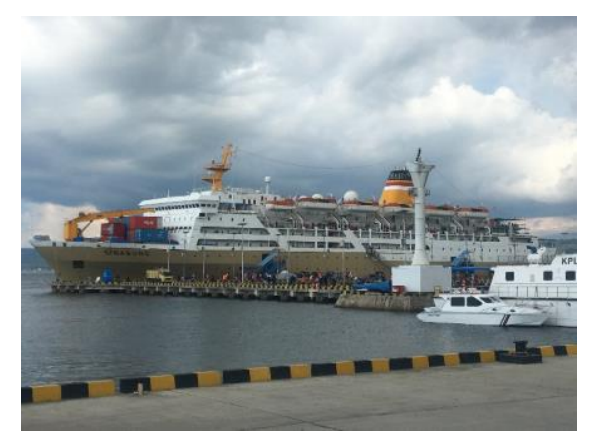

Gambar 1 KM. Sinabung di Pelabuhan Betoambari Baubau

Perjalanan menggunakan KM. Sinabung dilakukan secara bertahap dengan berlabuh untuk menurunkan dan menaikkan penumpang sesuai dengan rute. Aktivitas utama yang dilakukan penumpang ketika menggunakan KM. Sinabung meliputi embarkasi, perjalanan laut dan debarkasi (Cox \& Long, 2004). Embarkasi merupakan aktivitas yang dilakukan penumpang masuk kedalam kapal kemudian menemukan ruangan atau kelas kamar sesuai dengan tiket. Perjalanan laut adalah aktivitas yang dilakukan penumpang di dalam kapal dari awal perjalanan hingga sampai pada Pelabuhan sesuai tujuan. Sedangkan debarkasi adalah aktivitas yang dilakukan penumpang keluar dari dalam kapal menuju area Pelabuhan. Berdasarkan hasil observasi, kegiatan embarkasi ditemukan keramaian dan kontak fisik oleh penumpang pada jalur sirkulasi disebabkan mengalami kebingungan dan tersesat untuk mencari kamar atau tempat tidur.

Sirkulasi penumpang pada KM. Sinabung dipengaruhi oleh perpindahan penumpang yang naik dan turun di Pelabuhan khususnya pergerakkan penumpang (human traffic) di dalam kapal dan proses mencari jalan. Wayfinding dapat didefinisikan sebagai kemampuan untuk menemukan jalan menuju suatu tempat atau lokasi (Passini, 1984). Wayfinding merupakan sebuah kegiatan yang melibatkan manusia sebagai objek utama yang kemudian mempersepsi, mengartikan dan dipengaruhi oleh faktor manusia, faktor lingkungan, dan faktor informasi yang tersedia (Farr et al., 2012a). Faktor lingkungan menurut kevin lynch secara tidak langsung memiliki elemen-elemen mirip dalam menunjang kegiatan menemukan arah. Klasifikasi elemen lingkungan buatan meliputi, paths, edges, districts, nodes, dan landmarks (Mehrhoff, 1988).

Elemen pertama Paths atau jalan merupakan elemen linkungan buatan dimana seorang individu bergerak termasuk jalan, jalan setapak, jalur kereta api, kanal, dan jalur transit. Paths adalah fitur yang paling dominan dari lingkungan binaan karena kebutuhan fungsional mereka untuk memungkinkan orang untuk berpindah dari satu lokasi ke lokasi lain. Paths, memungkinkan untuk terbentuknya arah yang jelas dan berkontribusi terhadap perasaan seseorang terhadap besaran ruang dalam hal jarak yang ditempuh. Edges adalah batas antara dua area dan bertindak sebagai referensi lateral atau batas. Contohnya termasuk dinding, 
pantai, tepi pembangunan, dan potongan jalan kereta api. Meskipun tidak dominan seperti jalan atau path, edges memainkan peran penting dalam mengatur lingkungan yang dibangun. (Rafsyanjani \& Purwantiasning, 2020) Edges adalah fitur pengorganisasian yang penting, terutama dalam peran menyatukan area umum. Elemen berikutnya, districts, adalah elemen dari lingkungan yang memiliki karakter umum yang dapat dikenali (Mehrhoff, 1988).

Elemen districts umumnya diakui secara internal oleh individu dan cenderung digunakan sebagai titik referensi eksternal ketika seseorang melewati atau melakukan perjalanan pada suatu tempat. (Wohl, 2017) Nodes adalah titik-titik strategis di mana seseorang dapat memasuki lingkungan dan umumnya merupakan persimpangan atau konvergensi jalur, tempat istirahat dalam transportasi atau persimpangan. Nodes ditemukan di semua lingkungan dan karenanya keputusan harus dibuat pada lokasi tersebut. Pada persimpangan jalan atau nodes, minat individu untuk memperhatikan lingkungan cenderung tinggi, Hal tersebut menyebabkan nodes menjadi tempat yang logis untuk memasang peta dan papan direktori/informasi. Elemen terakhir, landmarks, adalah titik referensi eksternal seperti menara, kubah, bukit, dan tanda pada bangunan(Lamit, 2004). Titik-titik ini umumnya bersifat lokal dan hanya terlihat oleh lingkungan terbatas.

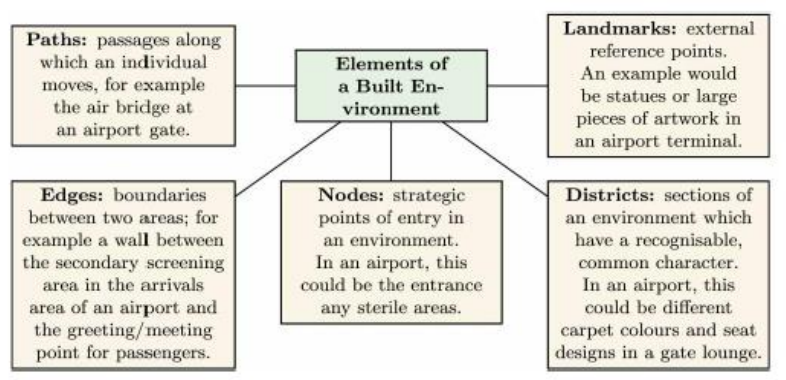

Gambar 25 Elemen buatan kevin lynch (Farr et al., 2012b)

Ke lima elemen tersebut tidak berdiri sendiri tetapi saling menunjang satu sama lain. Apabila penumpang mengalami proses wayfinding yang tidak baik, maka penumpang akan menjadi kebingungan dan tersesat yang berdampak pada rasa tidak kenyamanan dan mempengaruhi lama dan tidaknya proses embarkasi pada kapal

Pemahaman masyarakat terhadap lingkungan buatan, elemen, dan fungsinya memiliki atau tidak memiliki pengetahuan yang lengkap secara umumnya menggunakan kemampuan instuisi dan ekspektasi atau harapan terhadap lingkungan mereka. Kemampuan tersebut digunakan berdasarkan hasil pengalaman mereka berhubungan lingkungan buatan dan elemen sebagai cara untuk berkomunikasi (Frankenstein et al., 2010). Proses wayfinding pada individu dibentuk atas keputusan yang dipengaruhi oleh image yang diharapkan dan tingkah laku atau kebiasaan yang direncanakan (Passini, 1984). Kemampuan tersebut menunjukkan keadaan mental map dari penumpang. Jika image sesuai yang diharapkan maka akan mengikuti kebiasaan yang pernah dilakukan sehingga menghasilkan pola tindakan yang diharapkan dan jika image tidak sesuai dengan kebiasaan yang pernah dilakukan maka akan menghasilkan sebuah tindakan baru. (Passini, 1984). Tindakan tersebut akan menciptakan pengalaman secara kognitif dan psikologis yang berpengaruh kepada kenyamanan dan keamanan penumpang dalam proses embarkasi.

\section{Metode}

Metodologi penelitian yang digunakan yakni metodologi kualitatif dengan pendekatan studi kasus adalah suatu serangkaian kegiatan ilmiah yang dilakukan secara intensif, terinci dan 
mendalam tentang suatu program, peristiwa dan aktivitas baik pada tingkat perorangan, sekelompok orang, lembaga atau organisasi untuk memperoleh pengetahuan mendalam tentang peristiwa tersebut (Rahardjo, 2017). Penelitian kualitatif digunakan sebagai metodologi penelitian karena kejadian tersebut khusus terjadi di kapal dan faktor yang mempengaruhinya di studi secara holistik atau menyeluruh sehingga data diperoleh langsung pada lingkungan yang nyata pada kegiatan embarkasi di KM. Sinabung. Metode kualitatif adalah jenis penelitian yang memahami dan menafsirkan makna suatu peristiwa interaksi tingkah laku manusia dalam kondisi alami (natural setting) secara mendalam. (Gunawan, 2013).

\section{Metode Analisis}

Analisis yang dilakukan pada lingkungan interior kapal digunakan untuk mengetahui hubungan organisasi ruang terhadap wayfinding. Setelah observasi lingkungan telah dilakukan maka selanjutnya mengidentifikasi ruang menggunakan teori Kevin Lynch dan jalur sirkulasi pada proses embarkasi berdasarkan denah untuk menemukan jalur pergerakkan penumpang, Setelah data di analisis dan diperoleh hasil temuan maka di elaborasi untuk memperoleh kesimpulan secara menyeluruh dari penelitian ini.

\section{Metode Pengumpulan Data}

Pada penelitian cara yang digunakan untuk memperoleh data melalui observasi. Observasi yang di lakukan di KM. Sinabung meliputi 2 aktivitas yakni observasi pada proses embarkasi dan observasi pada area ruang fasilitas yang boleh digunakan oleh penumpang yang tersebar dari dek 1 hingga dek 7. Pada proses embarkasi di KM. Sinabung bermula dari pintu masuk area transisi dek/lantai 4. Penumpang masuk kedalam kapal kemudian mencari ruang kamar atau tempat tidur yang tersebar dari dek 2 hingga dek 6 . Dalam teknik observasi ini peneliti bertindak sebagai partisipan tidak langsung dengan tidak mengintervensi kebiasaan dan respon subjek. Observasi yang dilakukan meliputi hal-hal berikut:

1. Aktivitas Embarkasi Penumpang

Aktivitas subjek bertujuan untuk mengetahui kegiatan apa saja yang dilakukan penumpang ketika proses embarkasi. observasi dilakukan dengan metode shadowing adalah salah satu metodologi penelitian observasi individual secara dekat kepada partisipan pada periode waktu tertentu, terjadi secara alami untuk mendapatkan wawasan secara fokus dan khusus yang relevan (McDonald, 2005). Observasi dilakukan dengan memperhatikan tingkah laku penumpang dari area transisi hingga menuju kamar atau tempat tidur sesuai dengan tiket. Metode shadowing yang dapat dilakukan pada penumpang berjumlah 12 orang yang terbagi menjadi 4 kelompok. 3 kelompok yang dilakukan observasi mengalami proses tanpa diketahui (natural setting) berjumlah 8 orang. Proses shadowing dilakukan dengan cara mengikuti penumpang dari belakang dan melakukan dokumentasi berupa video.

\section{Organisasi Ruang}

Organisasi ruang merupakan lokasi ruangan dan fasilitas di dalam KM. Sinabung. Ruangan yang di observasi adalah dek 1 hingga dek 7 dengan melakukan dokumentasi berupa foto pada setiap dek. Lokasi setiap ruangan dan fasilitas dapat diketahui melalui denah kapal.

3. Jalur Sirkulasi Ruang

Jalur sirkulasi ruang merupakan jalur pergerakkan penumpang yang terbentuk dari organisasi ruang sebagai fasilitas berpindah tempat atau ruangan. Observasi pada jalur sirkulasi di KM. Sinabung berada pada dek 2 hingga dek 7 melalui denah kapal. 


\section{Hasil dan Pembahasan}

Organisasi ruang berdasarkan hasil observasi lapangan di kaji menggunakan teori kevin lynch, jalur sirkulasi ruang, jalur sirkulasi penumpang, dan titik kendala.

\section{Teori Kevin Lynch}

Lima elemen lingkungan buatan manusia menurut kevin lynch secara umum dapat di identifikasi berdasarkan lingkungan interior KM. Sinabung yakni, Path, atau jalur-jalur jalan berupa jalur pergerakkan dan sirkulasi penumpang yakni jalur antar ruang, jalur koridor, dan tangga antar dek atau lantai kapal. Nodes, atau titik temu antar jalur, titik strategis, pertemuan dan memiliki karakter kuat pada ruangan kapal berupa area transisi dan area lobi. Edge, atau batas-batas wilayah ditunjukkan pada organisasi ruangan, berupa dinding, dan sekat antar ruang pada interior kapal. District, atau merupakan wilayah homogen yang berbeda dengan wilayah lainnya (Edi Purwanto, 2001), adanya perbedaan mencolok, berupa area kelas kamar kapal. Landmark, atau penanda, menandai sebuah tempat, mengarahkan arah seseorang berupa penunjuk arah, hiasan dinding, lukisan pada interior kapal.

Secara khusus elemen tersebut dapat di identifikasi dengan menggunakan denah kapal dari dek 2 hingga 7 sebagai area yang dapat di gunakan oleh penumpang sebagai berikut :

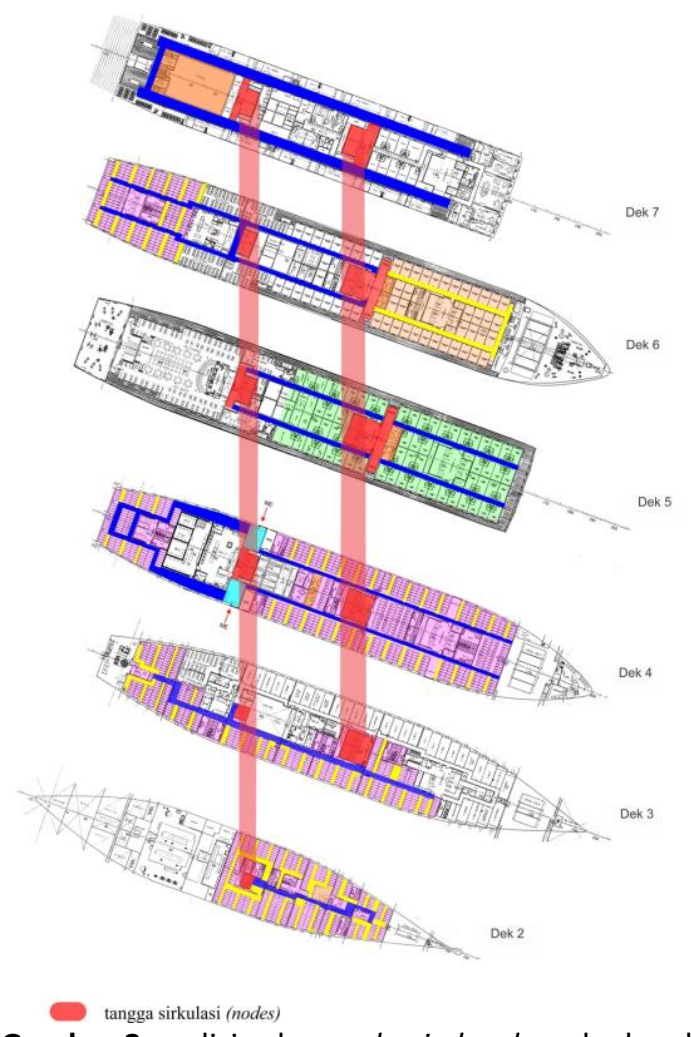

Gambar 3 analisis elemen kevin lynch pada denah kapal

Elemen kevin lynch terhadap organisasi ruang KM. Sinabung menghasilkan interpretasi ruang sebagai berikut :

Tabel 1 tabel interpretasi elemen kevin lynch.

\begin{tabular}{|l|l|c|}
\hline No. & $\begin{array}{c}\text { Data Hasil Observasi Ruangan KM. } \\
\text { Sinabung }\end{array}$ & $\begin{array}{c}\text { Interpretasi Menurut } \\
\text { Teori Kevin Lynch }\end{array}$ \\
\hline 1. & Area pintu masuk/area transisi dek 4 & nodes \\
\hline 2. & Tangga sirkulasi & nodes \\
\hline
\end{tabular}




\begin{tabular}{|l|l|c|}
\hline 3. & Area kamar kelas ekonomi & District \\
\hline 4. & Area kamar kelas 2C, 2D & District \\
\hline 5. & Area kamar kelas 1A, 1B & District \\
\hline 6. & Mini theater & landmark \\
\hline 7. & Toko dan area informasi dek 4 \\
\hline 8. & $\begin{array}{l}\text { Area penukaran kunci dan } \\
\text { area informasi dek 5 }\end{array}$ & landmark \\
\hline 9. & $\begin{array}{l}\text { Area penukaran kunci dan } \\
\text { area informasi dek 6 }\end{array}$ & landmark \\
\hline 10. & musala & landmark \\
\hline 11. & Area balkon luar & path \\
\hline 12. & $\begin{array}{l}\text { Jalur sirkulasi menuju kamar / tempat } \\
\text { tidur }\end{array}$ \\
\hline
\end{tabular}

Sumber : pribadi

Berdasarkan hasil tersebut maka didapatkan dua tangga sirkulasi dan area transisi (nodes) menjadi titik penting untuk menentukan keputusan pengambilan arah. Hal tersebut berhubungan dengan jalur sirkulasi (path) yang menghubungan area atau district berupa kabin kelas 1A-1B, kabin kelas 2C-2D, kabin kelas ekonomi. Maka daripada itu informasi berupa sistem penanda dan informasi secara langsung harus ditempatkan pada area tangga sirkulasi dan area sebelum tangga sirkulasi.

\section{Jalur Sirkulasi Ruang}

Penumpang pertama kali masuk melalui area transisi dek 4. Penumpang selanjut memiliki tangga sirkulasi 3 lokasi kamar yang tersebar dari dek 2 hingga dek 7. Terdapat 3 jenis kamar yakni kamar kelas ekonomi, kamar kelas 2C-2D, dan kamar kelas 1A-1B. berdasarkan hasil observasi terdapat 3 Tangga sirkulasi utama pada KM. Sinabung. Tangga Sirkulasi yang dapat digunakan adalah tangga sirkulasi 1 dan 2 sedangkan tangga sirkulasi 3 digunakan jika hanya terjadi keadaan darurat atau kecelakaan pada kapal. Tangga sirkulasi 3 juga cenderung mengarah pada ruangan yang kru kapal dan ruangan kelas 1A-1B dan 2C-2D yang tertutup dan tidak boleh dilalui oleh penumpang kelas ekonomi. Proses embarkasi penumpang dimulai dari dek 4 area transisi. Penumpang kemudian akan menggunakan tangga sirkulasi 1 dan tangga sirkulasi 2. Tangga sirkulasi 1 terhubung langsung dengan area transisi. Ukuran area tangga sirkulasi 1 memiliki ukuran yang lebih kecil dibandingkan dengan tangga sirkulasi 2. Dari hasil analisis tersebut maka diperoleh jalur efektif yang dapat digunakan sebagai berikut:

\section{Penumpang Kelas Ekonomi}

Penumpang kelas ekonomi masuk pertama kali melalui dek 4 area transisi. Kabin kelas ekonomi tersebar dari dek 2 hingga dek 5. Bagi penumpang kelas ekonomi dapat menggunakan tangga sirkulasi 1 untuk bergerak menuju kebawah yakni dek 2 dan keatas menuju dek 5. Tangga sirkulasi 1 efektif digunakan karena jumlah kapasitas penumpang kelas ekonomi yang besar dan terhubung langsung dengan area transisi. 


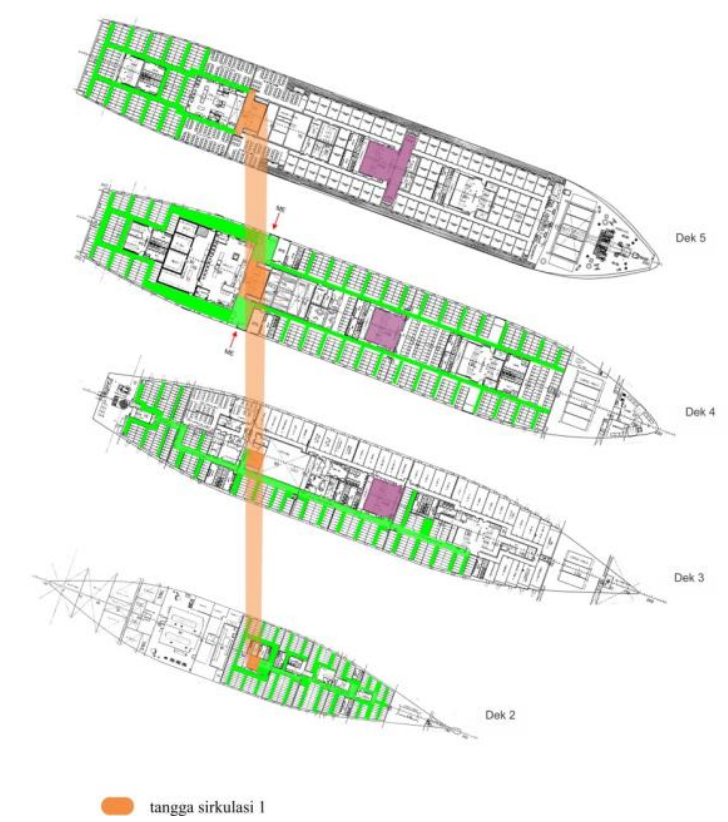

Gambar 4 jalur efektif pergerakan penumpang kelas ekonomi

2. Penumpang Kelas $2 \mathrm{C}-2 \mathrm{D}$

Penumpang kelas 2C-2D masuk pertama kali melalui dek 4 area transisi. Kabin kelas 2C-2D berada pada dek 5 sehingga dapat menggunakan tangga sirkulasi 2 untuk langsung menuju ruangan tersebut. Jalur tersebut efektif digunakan karena lokasi kabin yang berdekatan dengan tangga sirkulasi 2 .

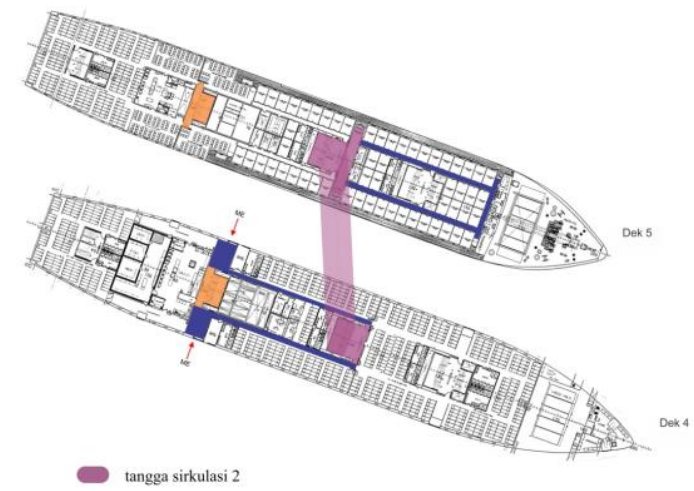

Gambar 5 jalur efektif pergerakan penumpang kelas 2C-2D

3. Penumpang Kelas $1 \mathrm{~A}-1 \mathrm{~B}$

Penumpang kelas $1 \mathrm{~A}-1 \mathrm{~B}$ masuk pertama kali melalui dek 4 area transisi. Kabin kelas 1A-1B berada pada dek 6 sehingga dapat menggunakan tangga sirkulasi 2 untuk langsung menuju area kamar tersebut. Jalur tersebut efektif digunakan karena area kamar berdekatan dengan jalur tangga sirkulasi 2 . 


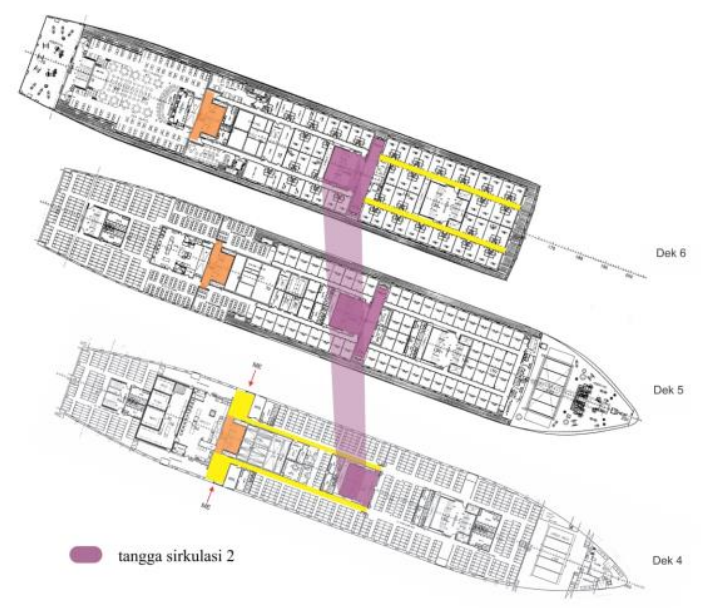

Gambar 6 jalur efektif pergerakan penumpang kelas 1A-1B

Berdasarkan dari hasil analisis tersebut, maka jalur sirkulasi penumpang secara efektif pada proses embarkasi penumpang secara lengkap yakni bermula dari dek/lantai 4 area transisi kapal. Penumpang masuk melalui tangga penyeberangan ke dalam kapal melalui pintu utama yang berada di area belakang kapal. Setelah penumpang masuk akan melalui area transisi dek/lantai 4. Selanjutnya penumpang akan memilih 3 jalur sirkulasi. Jalur sirkulasi menuju kamar kelas ekonomi melalui tangga sirkulasi 1 ke lantai atas menuju dek 5 sedangkan kebawah menuju dek 3 dan dek 2. Penumpang kelas 2C, $2 \mathrm{D}$ dan kelas $1 \mathrm{~A}$ dan $1 \mathrm{~B}$, melalui tangga sirkulasi 2 menuju keatas atas yakni dek 5 bagi kelas 2C dan 2D dan dek 6 bagi kelas $1 \mathrm{~A}$ dan $1 \mathrm{~B}$.

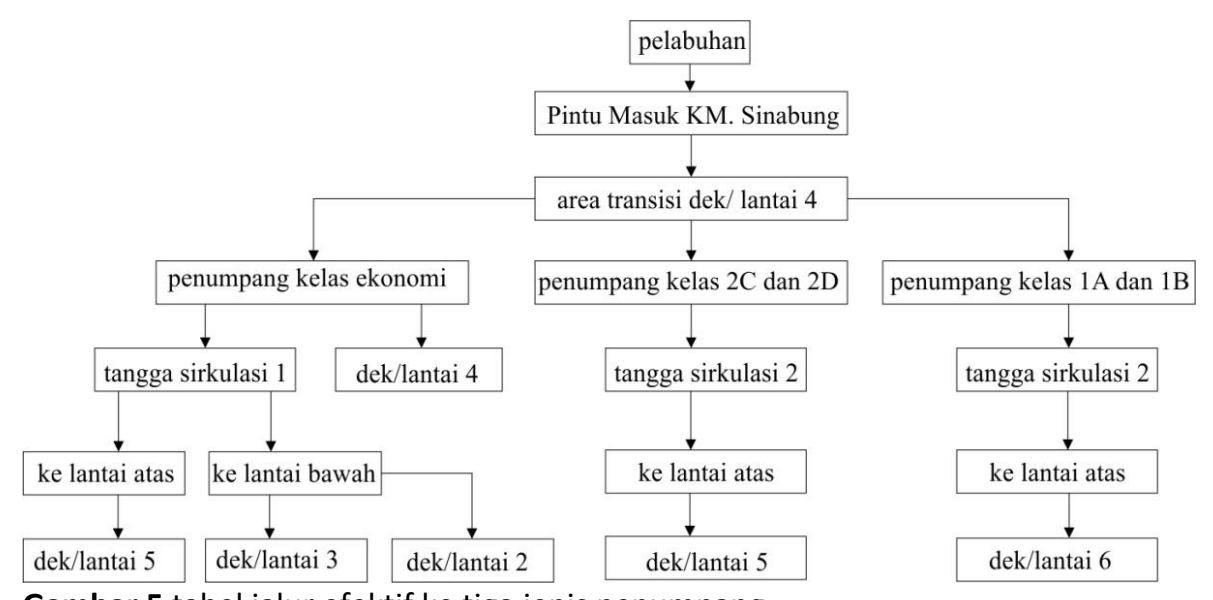

Gambar $\mathbf{5}$ tabel jalur efektif ke tiga jenis penumpang

\section{Jalur Sirkulasi Penumpang}

Analisis jalur sirkulasi penumpang dilakukan dengan cara metode shadowing. Hasil observasi yang dilakukan terbagi menjadi 3 kelompok sebagai berikut :

1. Kelompok A

Penumpang kelompok A terdiri atas 1 keluarga meliputi 1 orang laki-laki dewasa, 1 orang perempuan dewasa, 1 orang anak perempuan kecil, dan bayi. Mereka merupakan penumpang dengan tujuan kelas $2 \mathrm{C}$ dan $2 \mathrm{D}$. perjalanan di mulai dari area transisi dek/lantai 4 hingga menuju area penukaran kunci kamar di dek/lantai 5. 


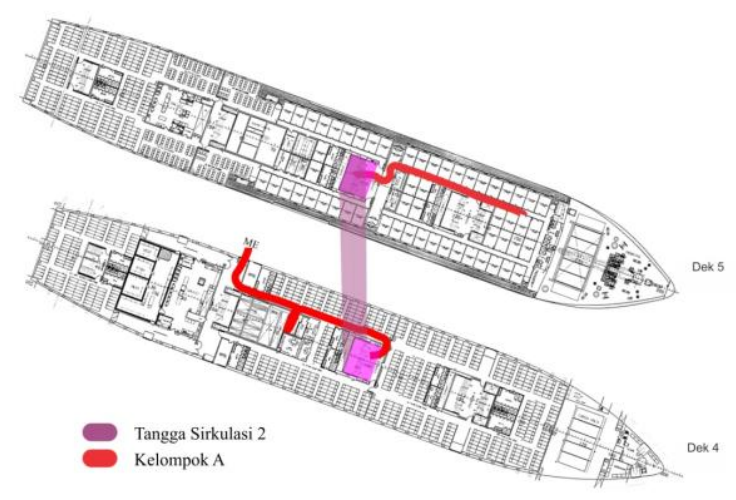

Gambar 7 jalur pergerakan penumpang kelompok A

Penumpang kelompok A berdasarkan hasil observasi bergerak dengan bertanya terlebih dahulu kepada kru kapal, selanjutnya mengikuti arahan tersebut. Istri dan anak perempuannya mengikuti ayahnya dari belakang. Dalam kegiatan wayfinding tersebut ruangan terasa gelap dan banyak terdapat barang di sepanjang jalur sirkulasi. Selanjutnya penumpang berbelok ke jalur yang salah disebabkan oleh penanda tersebut hanya berubah nomor dan tidak memiliki penanda arah fasilitas yang jelas. Penumpang kemudian keluar dan selanjutnya menuju pada jalur pertigaan. Pada lokasi tersebut terdapat kru kapal yang memberikan informasi secara langsung sehingga penumpang dapat langsung menuju lokasi kamar/tempat tidur di KM. Sinabung yang berada pada dek 5 .

2. Kelompok B

Kelompok B terdiri atas : 1 keluarga yakni 1 orang dewasa, 1 orang anak laki-laki. Mereka merupakan penumpang dengan tujuan kelas ekonomi dek/lantai 4.

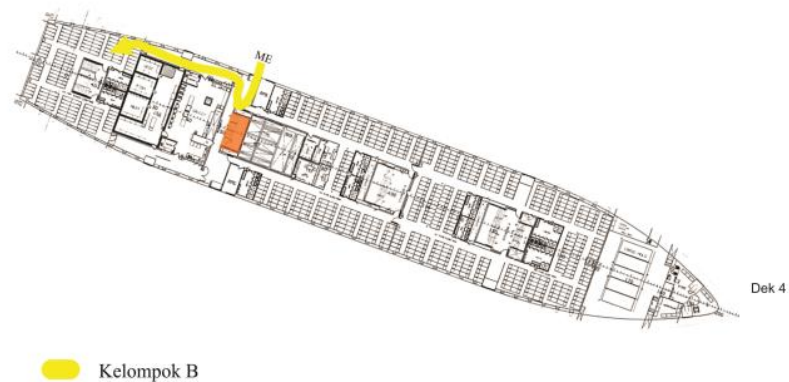

Gambar 8 jalur pergerakan penumpang kelompok B

Penumpang kelompok B berdasarkan hasil observasi bergerak dengan bertanya terlebih dahulu kepada kru kapal, selanjutnya bergerak sesuai arahan. Untuk meyakinkan kembali penumpang bertanya kepada penumpang lainnya. Penumpang sampai pada lokasi yang dituju.

3. Kelompok C

Kelompok $\mathrm{C}$ terdiri atas 3 orang laki-laki dewasa, Mereka merupakan penumpang dengan tujuan kelas ekonomi. 


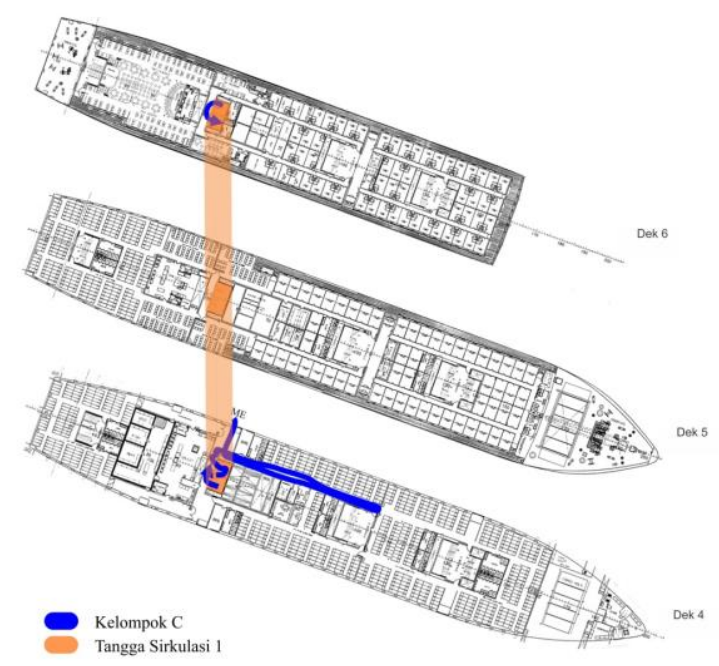

Gambar 9 jalur pergerakan penumpang kelompok $C$

Penumpang kelompok $\mathrm{C}$ berdasarkan hasil observasi terdiri atas sekelompok laki-laki dewasa yang bergerak berdasarkan hasil arahan dari kru kapal maupun penumpang kapal. penumpang mengalami disorientasi dan bergerak mencari hingga sampai ke dek 6 . Setelah itu turun kembali menuju area transisi untuk bertanya kembali kepada kru kapal. Hingga akhir observasi penumpang tidak menemukan lokasi kamar yang dituju.

Berdasarkan dari hasil kegiatan shadowing terhadap tiga kelompok tersebut dapat disimpulkan penumpang kelompok A dan kelompok $C$ mengalami kesulitan wayfinding sedangkan kelompok B tidak. Proses tersebut terjadi disebabkan jalur masuk dan letak kamar atau tempat tidur berada pada dek yang berbeda dari letak area transisi sehingga jalur dan letak tangga sirkulasi menjadi bagian penting dalam melakukan wayfinding di KM. Sinabung.

\section{Titik Kendala}

Titik kendala merupakan lokasi atau area terjadinya keramaian pada jalur sirkulasi yang disebabkan oleh penumpang pada aktivitas embarkasi. Analisis ini melibatkan hasil dari observasi dan aktivitas shadowing. Masalah wayfinding muncul pada area transisi dek 4 dan 2 jalur sirkulasi menuju tangga sirkulasi 2. Lokasi tersebut di sebabkan oleh penumpang yang berhenti dan berkumpul sehingga terjadi kontak fisik dan perlu adanya bantuan dari kru kapal untuk memberikan informasi secara langsung. Lokasi terjadi titik kendala dapat di identifikasi melalui denah dek/lantai 4 sebagai berikut:

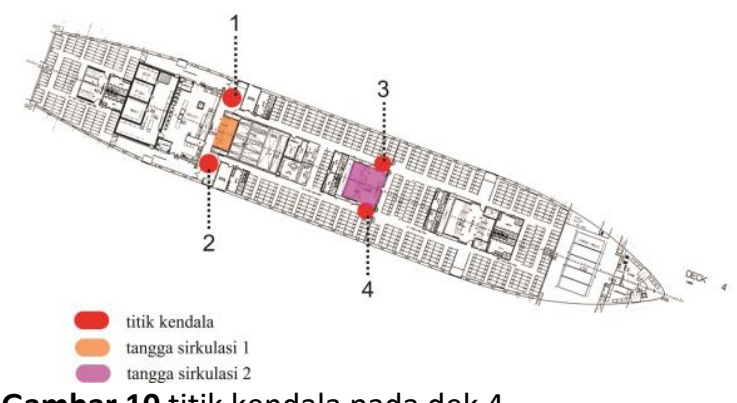

Gambar 10 titik kendala pada dek 4

Terdapat 4 titik kendala yang menjadi area keramaian pada aktivitas embarkasi. Lokasi tersebut berada pada dek 4 yang berdekatan dengan kedua tangga sirkulasi. pada area 1 dan 2 
merupakan area transisi ketika penumpang pertama kali masuk dan berdekatan dengan tangga sirkulasi 1. Area tersebut merupakan area pertama kali dilalui penumpang Sedangkan area 3 dan 4 merupakan area yang berdekatan tangga dengan tangga sirkulasi 2. 4 titik kendala tersebut merupakan area persimpangan atau pertigaan sehingga cenderung ramai dan banyak penumpang berhenti dan diam disebabkan kebingungan memilih arah.

Berdasarkan hasil analisis organisasi ruang diatas maka interior KM. Sinabung berdasarkan teori Kevin lynch terhadap jalur sirkulasi penumpang sangat di pengaruhi oleh adanya persimpangan jalan atau nodes sebagai area untuk mengambil keputusan orientasi. Kedua tangga sirkulasi menjadi (nodes) penting bagi penumpang untuk bergerak dan berpindah ruang. Penumpang pertama kali masuk akan melewati area transisi yang terhubung dengan 3 jalur sirkulasi menuju area yang kamar atau tempat tidur sehingga menjadi titik pengambilan keputusan pertama. Dari hasil observasi penumpang cenderung menunggu dan berkumpul pada area transisi sehingga terjadi keramaian dan kontak fisik antar penumpang. Berdasarkan hasil metode shadowing penumpang memiliki pola untuk kembali area transisi ketika terjadi kebingungan atau disorientasi sehingga membuat area menjadi ramai dan terjadi kontak fisik penumpang sehingga ruangan menjadi sempit dan sulit untuk bergerak. Lingkungan wayfinding dapat dikatakan jika memenuhi kriteria arsitektural (organisasi ruang), signage (sistem penanda), dan elemen non fisik lainnya (Passini, 1984). Berdasarkan hasil kesimpulan tersebut maka lingkungan KM. Sinabung dapat dikatakan tidak memenuhi kriteria tersebut berdasarkan aktivitas embarkasi.

\section{Simpulan}

Organisasi ruang memiliki hubungan dengan keberhasilan wayfinding penumpang di KM. Sinabung pada proses embarkasi yakni besaran ukuran jalur sirkulasi terhadap jumlah penumpang. Jalur sirkulasi penumpang pada titik kendala 1 dan 2 berhubungan langsung dengan area pemberhentian sementara (bordes) tangga sirkulasi 1. Hal tersebut disebakan ukuran area yang kecil dan tidak dapat menampung pergerakkan penumpang yang masuk dari area transisi khususnya penumpang kelas ekonomi sebagai jalur sirkulasi utama sehingga terjadi keramaian dan kontak fisik.

Saran untuk perancang dan desainer solusi dari permasalahan tersebut maka pada perancangan denah dapat dilakukan dengan cara area pemberhentian (bordes) pada tangga sirkulasi 1 dek 4 dapat di perbesar dengan ukuran yang sama dengan tangga sirkulasi 2, atau dapat bertukar tempat dengan mempengaruhi ukuran fasilitas ruang lainnya. Hal tersebut bertujuan agar dapat meningkatkan kapasitas penumpang yang melakukan wayfinding pada aktivitas terutama penumpang kelas ekonomi dengan jumlah kapasitas penumpang lebih besar sehingga tidak terjadi keramaian dan kontak fisik antar penumpang. 


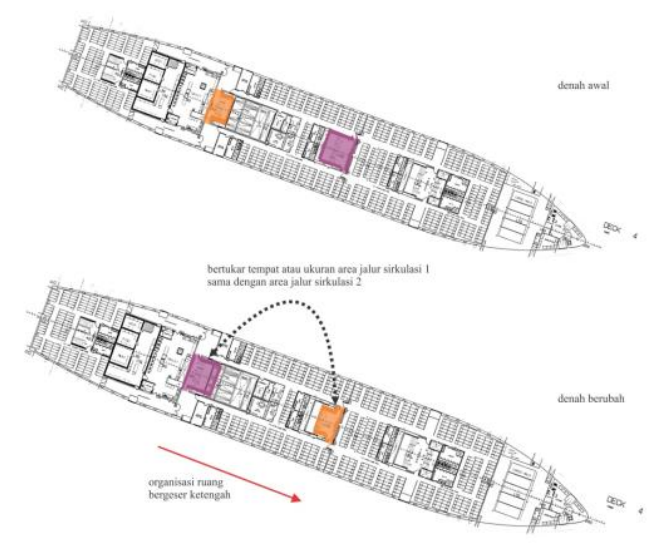

Gambar 10 Perubahan Luas Area Tangga Sirkulasi 1

\section{Ucapan Terima Kasih}

Terima kasih kepada Orang tua, Dosen Pembimbing, dan teman-teman dan segenap staff Magister Desain ITB yang telah memberi dukungan baik moral dan material untuk melakukan penelitian ini.

\section{Daftar Pustaka}

Cox, R., \& Long, J. C. (2004). Embarkation/disembarkation of cruise ship passengers between the terminal and the ship. Port Development in the Changing World, PORTS 2004, Proceedings of the Conference, 1-10. https://doi.org/10.1061/40727(2004)1

Edi Purwanto. (2001). PENDEKATAN PEMAHAMAN CITRA LINGKUNGAN PERKOTAAN (melalui kemampuan peta mental pengamat). DIMENSI (Jurnal Teknik Arsitektur), 29(1). http://puslit2.petra.ac.id/ejournal/index.php/ars/article/view/15748

Farr, A. C., Kleinschmidt, T., Yarlagadda, P., \& Mengersen, K. (2012a). Wayfinding: A simple concept, a complex process. Transport Reviews, 32(6), 715-743. https://doi.org/10.1080/01441647.2012.712555

Farr, A. C., Kleinschmidt, T., Yarlagadda, P., \& Mengersen, K. (2012b). Wayfinding: A simple concept, a complex process. In Transport Reviews. https://doi.org/10.1080/01441647.2012.712555

Frankenstein, J., Büchner, S. J., Tenbrink, T., \& Hölscher, C. (2010). Influence of geometry and objects on local route choices during wayfinding. Lecture Notes in Computer Science (Including Subseries Lecture Notes in Artificial Intelligence and Lecture Notes in Bioinformatics). https://doi.org/10.1007/978-3-642-14749-4_7

Gunawan, I. (2013). METODE PENELITIAN KUALITATIF. In academia.edu. https://www.academia.edu/download/62137147/3_Metpen-Kualitatif20200218117182-1a60wxc.pdf

Lamit, H. (2004). Redefining landmarks. Jurnal Alam Bina. 
McDonald, S. (2005). Studying actions in context: A qualitative shadowing method for organizational research. Qualitative Research, 5(4), 455-473. https://doi.org/10.1177/1468794105056923

Mehrhoff, W. A. (1988). The Image of the City. Urban Affairs Quarterly, 24(1), 46-68. https://doi.org/10.1177/004208168802400104

Passini, R. (1984). Spatial representations, a wayfinding perspective. Journal of Environmental Psychology. https://doi.org/10.1016/S0272-4944(84)80031-6

PELNI, A. R. P. (2020). Creating Value Through Sustainability.

Rafsyanjani, M. A., \& Purwantiasning, A. W. (2020). Kajian Konsep Teori Lima Elemen Citra Kota pada Kawasan Kota Lama Semarang. Arsir. https://doi.org/10.32502/arsir.v3i2.2219

Rahardjo, M. (2017). Studi kasus dalam penelitian kualitatif: konsep dan prosedurnya. http://repository.uin-malang.ac.id/1104/

Werft, M. (2014). Passenger ships for indonesia - Meyer Werft - PDF Catalogs / Documentation I Boating Brochures. https://pdf.nauticexpo.com/pdf/meyer-werft/passenger-shipsindonesia/31356-104421.html

Wohl, S. (2017). From form to process: Re-conceptualizing Lynch in light of complexity theory. Urban Design International. https://doi.org/10.1057/s41289-017-0048-6

Yahya kuncoro. (2020). Situs Resmi PT Pelayaran Nasional Indonesia (Persero). Transport Reviews. https://pelni.co.id/new-normal-transportasi-laut-pelni-optimis-jumlahpenumpang-meningkat 